\title{
Colorful Packages: Encapsulation of Fluorescent Proteins in Complex Coacervate Core Micelles
}

\author{
Antsje Nolles ${ }^{1,2}$ (D), Adrie H. Westphal ${ }^{1,3}$, J. Mieke Kleijn ${ }^{2}$, Willem J. H. van Berkel ${ }^{1}$ \\ and Jan Willem Borst ${ }^{1,3, *}$ \\ 1 Laboratory of Biochemistry, Wageningen University \& Research, Stippeneng 4, 6708 WE Wageningen, \\ The Netherlands; antsje.nolles@wur.nl (A.N.); adrie.westphal@wur.nl (A.H.W.); \\ willem.vanberkel@wur.nl (W.J.H.v.B.) \\ 2 Physical Chemistry and Soft Matter, Wageningen University \& Research, Stippeneng 4, 6708 WE \\ Wageningen, The Netherlands; mieke.kleijn@wur.nl \\ 3 MicroSpectroscopy Centre Wageningen, Wageningen University \& Research, Stippeneng 4, 6708 WE \\ Wageningen, The Netherlands \\ * Correspondence: janwillem.borst@wur.nl; Tel.: +31-317-483-724
}

Received: 23 May 2017; Accepted: 13 July 2017; Published: 19 July 2017

\begin{abstract}
Encapsulation of proteins can be beneficial for food and biomedical applications. To study their biophysical properties in complex coacervate core micelles (C3Ms), we previously encapsulated enhanced green fluorescent protein (EGFP) and its monomeric variant, mEGFP, with the cationic-neutral diblock copolymer poly(2-methyl-vinyl-pyridinium $)_{\mathrm{n}}-b$-poly(ethylene-oxide $)_{\mathrm{m}}$ $\left(\mathrm{P}_{2} \mathrm{MVP}_{\mathrm{n}}-b-\mathrm{PEO}_{\mathrm{m}}\right)$ as enveloping material. C3Ms with high packaging densities of fluorescent proteins (FPs) were obtained, resulting in a restricted orientational freedom of the protein molecules, influencing their structural and spectral properties. To address the generality of this behavior, we encapsulated seven FPs with $\mathrm{P}_{2} \mathrm{MVP}_{41}-b-\mathrm{PEO}_{205}$ and $\mathrm{P}_{2} \mathrm{MVP}_{128}-b-\mathrm{PEO}_{477}$. Dynamic light scattering and fluorescence correlation spectroscopy showed lower encapsulation efficiencies for members of the Anthozoa class (anFPs) than for Hydrozoa FPs derived from Aequorea victoria (avFPs). Far-UV CD spectra of the free FPs showed remarkable differences between avFPs and anFPs, caused by rounder barrel structures for $a v$ FPs and more elliptic ones for anFPs. These structural differences, along with the differences in charge distribution, might explain the variations in encapsulation efficiency between $a v \mathrm{FPs}$ and $a n \mathrm{FPs}$. Furthermore, the $a v \mathrm{FPs}$ remain monomeric in C3Ms with minor spectral and structural changes. In contrast, the encapsulation of anFPs gives rise to decreased quantum yields (monomeric Kusabira Orange 2 (mKO2) and Tag red fluorescent protein (TagRFP)) or to a $\mathrm{pK}_{\mathrm{a}}$ shift of the chromophore (FP variant mCherry).
\end{abstract}

Keywords: Anthozoa; chromophore; circular dichroism; diblock copolymer; dynamic light scattering; fluorescence correlation spectroscopy; Hydrozoa; polyelectrolyte; protein structure; steady-state fluorescence

\section{Introduction}

Fluorescent proteins (FPs) are nowadays indispensable in life sciences [1-4]. The discovery of FPs started in the early 1960s with studies on the identification of the glow of jellyfish from Aequorea victoria by Osamu Shimomura [5]. The protein emitting the green light was called green fluorescent protein (GFP) [6] and its sequence was obtained in 1992 by Prasher [7]. In the following years, a wide variety of GFP variants with different colors and improved brightness and stability were developed. However, there were no GFP variants with emission maxima above $527 \mathrm{~nm}$ [4]. This limitation was overcome by cloning of GFP homologs from non-bioluminescent reef corals of the Anthozoa class [8-11]. From this class, a palette of FPs became available emitting at longer wavelengths. Consequently, the number of 
applications of FPs has exploded, which is mainly because they can be genetically introduced into cells, tissues or whole organisms. This allows using FPs for multicolor imaging and for studying protein interactions [12-14]. Besides using FPs as fusion tags and biosensors, they have also been used as model proteins in encapsulation studies [15-18].

Encapsulation of proteins is of interest for food and biomedical applications, because it can protect and stabilize the encapsulated protein. Encapsulation of FPs allows the use of fluorescence techniques for the characterization of protein-containing micelles [18].

Previously, we reported on the encapsulation of enhanced green fluorescent protein (EGFP) and its monomeric variant (mEGFP) in complex coacervate core micelles (C3Ms) with the cationic-neutral diblock copolymer poly(2-methyl-vinyl-pyridinium $)_{\mathrm{n}}-b$-poly(ethylene-oxide $)_{\mathrm{m}}\left(\mathrm{P}^{2} \mathrm{MVP}_{\mathrm{n}}-b-\mathrm{PEO}_{\mathrm{m}}\right)$ as enveloping material $[18,19]$. The two GFP variants showed considerable differences in their spectral and structural properties upon encapsulation. Encapsulation into C3Ms promoted dimerization of EGFP but not of mEGFP, due to the difference in dissociation constant $\left(K_{\mathrm{D}}, 0.11 \mathrm{mM}\right.$ for EGFP and $74.0 \mathrm{mM}$ for mEGFP [20]). Dimerization of EGFP upon encapsulation in C3Ms results in a $\mathrm{p} K_{\mathrm{a}}$ shift of its chromophore, leading to specific changes in the spectral and structural properties of EGFP [19].

The aim of the present study is to determine whether structural and spectral changes are common upon encapsulation of members of the visible fluorescent protein family. Therefore, we encapsulated a variety of fluorescent proteins covering the whole visible spectrum (Figure 1). We investigated seven differently colored FPs: four FPs derived from Aequorea victoria GFP (avFPs: strongly enhanced blue fluorescent protein 2 (SBFP2), mTurquoise2, mEGFP, and strongly enhanced yellow fluorescent protein 2 (SYFP2), from class Hydrozoa) and three FPs from class Anthozoa (anFPs: monomeric Kusabira Orange 2 (mKO2), Tag red fluorescent protein (TagRFP), and mCherry). The seven FPs originate from four different ancestors: one from the Hydrozoa class and three from the Anthozoa class. Even though these proteins have a comparable fold and function, the amino acid sequences vary between the different species (see Figure S1 and Table S1). The sequence identities among the avFPs are about $97 \%$, whereas the anFPs show about $25-30 \%$ similarity to the avFPs. Amongst the anFPs, TagRFP and mCherry show a higher sequence identity $(57 \%)$ than $\mathrm{mKO} 2$ does with these two proteins $(\sim 48 \%)$. The seven FPs contain about $10 \%$ of strictly conserved residues (Figure S1). These residues are mainly located at the end of beta-strands and in loops, except for the strictly conserved Gly67, Asp95, Arg96, and Glu222 amino acid residues, which are involved in the formation of the chromophore [21].

Some general properties of FPs are critical for understanding their structural and spectral properties. All FPs have an approximate molar mass of $27 \mathrm{kDa}$, constituting a single polypeptide chain of about 230 amino acids. They all share a fold consisting of an 11-stranded $\beta$-barrel with a length of $4.2 \mathrm{~nm}$ and a diameter of $2.4 \mathrm{~nm}$ (Figure 1A). The barrel is wrapped around a single distorted helix, which contains three amino acid residues that create the fluorophore. The fluorophore is formed via cyclization, dehydration, and oxidation of the amino acid residues located at positions 65-67 (mEGFP numbering, Figure 1B-H). Depending on the $\mathrm{pH}$ of the solution, the chromophore can exist in differing protonation states, which influences the spectral properties of the FP. Furthermore, the fluorophore is comprised of a highly conjugated $\pi$-electron resonance system that together with its environment accounts for the spectroscopic and photophysical properties of an FP.

The spectroscopic features of the seven FPs will be presented according to their absorption maxima. We start with strongly enhanced blue fluorescent protein (SBFP2), which was obtained by the Y66H substitution in GFP (Figure 1B) [22]. Turquoise FPs are obtained by a Y66W substitution in GFP (Figure 1C), which yields amongst others mTurquoise2 [23]. mTurquoise2 is especially characterized by its long mono-exponential fluorescence lifetime $(\tau=3.8 \mathrm{~ns})$, which makes it very suitable as a Förster resonance energy transfer (FRET) donor in conjunction with a yellow fluorescent protein as the acceptor. Originally, FPs are not monomeric, but this can be achieved with the A206K substitution, which is used in mEGFP [20]. The GFP variants with emission maxima at the longest wavelengths are yellow FPs, obtained by a T203Y substitution in GFP, and in this research we used SYFP2 (Figure 1E) [24]. This 
FP has a high extinction coefficient compared to other FPs $\left(\varepsilon_{S Y F P 2}=101000 \mathrm{M}^{-1} \cdot \mathrm{cm}^{-1}\right.$, see Table S2) making it a very suitable acceptor in FRET-pairs [24].

The chromophore structures of FPs from Anthozoa species generally have more extended $\pi$-systems, enabling higher excitation and emission wavelengths. Such a type of fluorophore is found in $\mathrm{mKO} 2$, which evolved from a fluorescent protein of the mushroom coral Fungia concinna, with a cysteine located at position 65 (mEGFP numbering, Figure 1F) $[9,25]$. mKO2 is very useful in multicolor imaging applications as it can be combined with cyan, green, yellow, and red FPs. A protein with an almost similar excitation maximum as $\mathrm{mKO} 2$ is TagRFP (Figure 1G), but this protein has been derived from the sea anemone Entacmaea quadricolor [10]. TagRFP has an even more extended $\pi$-system than $\mathrm{mKO} 2$, because it has a methionine located at position 65 (mEGFP numbering, Figure 1G). Next to that, TagRFP is one of the few FPs bearing a trans-isomerized chromophore. A protein that also contains a methionine at position 65 (mEGFP numbering) is mCherry, one of the "mFruit" FPs derived from Discosoma species [26,27]. mCherry shows a high photostability and its chromophore is rapidly formed (Figure 1H), which makes it very suitable as a FRET acceptor in combination with EGFP in fluorescence-lifetime imaging microscopy (FLIM) studies [28].

In this research, we used the diblock copolymers $\mathrm{P}_{2} \mathrm{MVP}_{41}-b-\mathrm{PEO}_{205}$ and $\mathrm{P}_{2} \mathrm{MVP}_{128}-b-\mathrm{PEO}_{477}$ to form C3Ms in combination with the above-mentioned FPs. We characterized the C3Ms with dynamic light scattering (DLS) and fluorescence correlation spectroscopy (FCS), and explored the effects of packing on the FPs with circular dichroism (CD) and fluorescence spectral analysis. The experimental data, and in particular the observed encapsulation efficiencies, are discussed in relation to what is known about the structural features of the FPs.

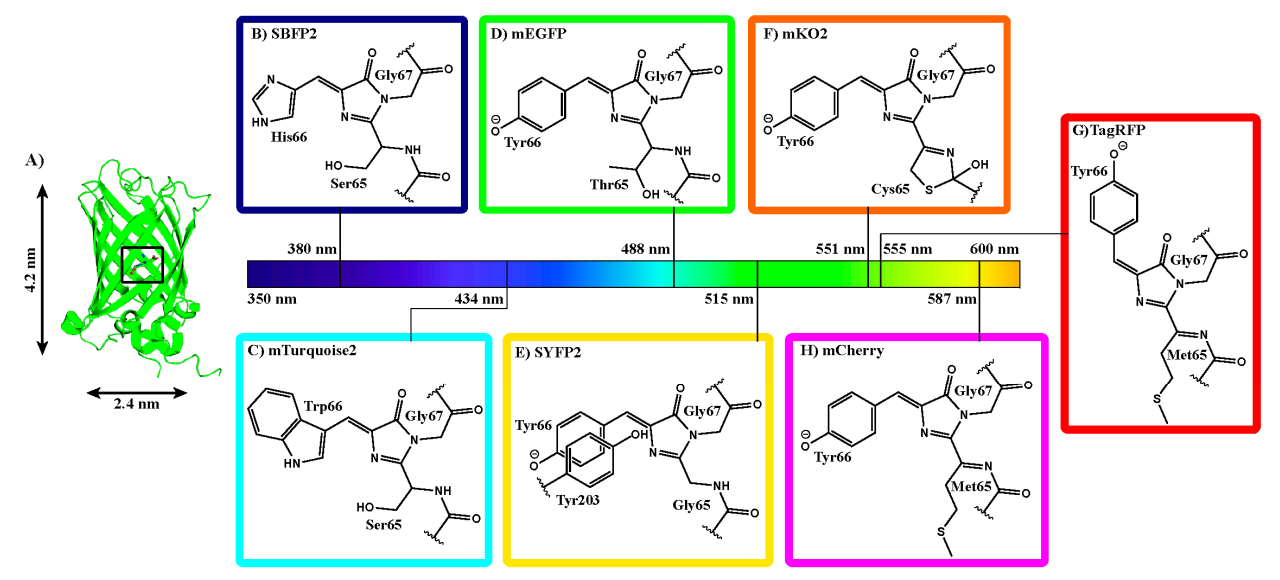

Figure 1. Chromophore properties of fluorescent proteins used in this research (A) Ribbon diagram of mEGFP with its chromophore in the center of the barrel (PDB entry 4EUL [29]); (B) Chromophore of SBFP2 made from Ser65, His66, and Gly67; (C) chromophore of mTurquoise2 made from Ser65, Trp66, and Gly67; (D) Chromophore of mEGFP made from Thr65, Tyr66, and Gly67 in the anionic form; (E) Chromophore of SYFP2 made from Gly65, Tyr66, and Gly67 in the anionic form with Tyr203 to extend the $\pi$-system; (F) Chromophore of $\mathrm{mKO} 2$ made from Cys65, Tyr66, and Gly67 in the anionic form; (G) Chromophore of TagRFP made from Met65, Tyr66, and Gly67 in the anionic form and in the trans-conformation and $(\mathbf{H})$ Chromophore of mCherry made from Met65, Tyr66 and Gly67 in the anionic form and in the cis-conformation. Absorption maxima are indicated on the spectral bar and fluorescence colors are indicated as box colors.

\section{Results}

In this work, we purified seven FPs using either the intein/chitin-binding-domain system (for mTurquoise2, SYFP2-His, and mCherry) or metal affinity chromatography (for SBFP2, mEGFP, $\mathrm{mKO} 2$, and TagRFP, see Section 4.2). The influence of the His-tag was tested by encapsulation of mTurquoise2 and of mTurquoise2-His [30]. We did not observe any differences in encapsulation 
properties between the two proteins; therefore, it is presumed that His-tags have no effects on our experiments using other FPs. The purified FPs have distinctive spectral properties. Figure 2 shows our recorded normalized fluorescence excitation and emission spectra of the FPs, which display maxima in agreement with those listed in literature (Table S2).
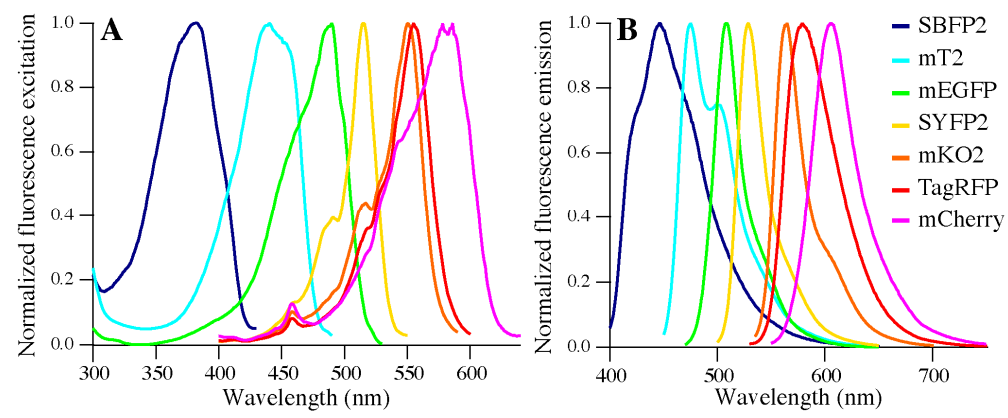

Figure 2. Normalized fluorescence (A) Excitation spectra and (B) Emission spectra of SBFP2, mTurquoise2 (mT2), mEGFP, SYFP2, mKO2, TagRFP and mCherry.

\subsection{Fluorescent Protein Charge Determination}

Measurements on encapsulated FPs in C3Ms are commonly performed at the preferred micellar composition (PMC), which is the ratio between protein and polymer at which the highest concentration of micelles is obtained $[18,19,31]$. The PMC is defined in terms of the total concentration of positively charged groups on the polymers and the net concentration of negative charges on the protein (see Equation (1), Section 4.5). The positive charge on the polymers is fixed due to quaternization, but the charge of the proteins varies with $\mathrm{pH}$. The amino acid residues on the protein surface determine to a great extent the net charge of the protein, which can be deduced from the protein's three-dimensional structure using the PROPKA software package [32,33]. For four of the studied FPs (mTurquoise2, mEGFP, TagRFP, and mCherry), a crystal structure is available in the RCSB Protein Data Bank [34] (Table 3). For the three other FPs (SBFP2, SYFP2, and mKO2), a Blast search was performed to obtain the most suitable template, which was then used for building homology models (Table 4).

The $\mathrm{p} I$ value for the four avFPs and for two an FPs (mKO2 and mCherry) is about 5.5, while TagRFP has a significantly higher $\mathrm{p} I$ value, $\sim 7.6$ (Table S2). To achieve similar electrostatic interactions between the polymers and the different FPs, we encapsulated all FPs at the $\mathrm{pH}$ at which they have a net negative charge of about 10 unit charges. Thus, TagRFP was encapsulated at $\mathrm{pH} 10$ and the other FPs at $\mathrm{pH} 9$ (Table 1). At these conditions, all FPs are stable [35].

Table 1. Results of PROPKA 3.1 analysis and preferred micellar composition (PMC) determination. The charge of the proteins was determined at $\mathrm{pH}$ 9, except for TagRFP (pH 10), with PROPKA 3.1 [32,33]. PMC $\left(F^{+}\right)$and hydrodynamic radii (with standard deviations) were determined with dynamic light scattering for all used fluorescent protein variants encapsulated using the two diblock copolymers.

\begin{tabular}{|c|c|c|c|c|c|}
\hline \multirow{2}{*}{$\begin{array}{c}\text { Fluorescent } \\
\text { Protein Variant }\end{array}$} & \multirow{2}{*}{ Charge } & \multicolumn{2}{|c|}{$\mathrm{P}_{2 M V P}^{41}-b-\mathrm{PEO}_{205}$} & \multicolumn{2}{|c|}{$\mathrm{P}^{2} \mathrm{MVP}_{128}-b-\mathrm{PEO}_{477}$} \\
\hline & & $\operatorname{PMC}\left(F^{+}\right)$ & Radius (nm) & $\operatorname{PMC}\left(F^{+}\right)$ & Radius (nm) \\
\hline SBFP2 & -8.96 & 0.75 & $38.3 \pm 0.5$ & 0.70 & $33.6 \pm 0.2$ \\
\hline mTurquoise2 & -11.30 & 0.70 & $37.1 \pm 1.0$ & 0.70 & $33.9 \pm 0.5$ \\
\hline mEGFP & -9.87 & 0.70 & $30.4 \pm 0.5$ & 0.65 & $32.2 \pm 0.2$ \\
\hline SYFP2 & -9.75 & 0.70 & $30.4 \pm 0.4$ & 0.60 & $35.2 \pm 0.7$ \\
\hline mKO2 & -13.09 & 0.65 & $25.7 \pm 0.5$ & 0.60 & $28.3 \pm 0.5$ \\
\hline TagRFP ${ }^{a}$ & -10.35 & 0.70 & $36.7 \pm 5.0$ & 0.65 & $33.3 \pm 1.9$ \\
\hline mCherry & -8.93 & 0.75 & $30.0 \pm 0.8$ & 0.75 & $35.1 \pm 1.0$ \\
\hline
\end{tabular}

${ }^{\text {a }}$ Values determined at $\mathrm{pH} 10$. 


\subsection{Preferred Micellar Composition (PMC)}

The seven FPs were encapsulated using two diblock copolymers with different lengths $\left(\mathrm{P}_{2} \mathrm{MVP}_{41}-b-\mathrm{PEO}_{205}\right.$ or $\left.\mathrm{P}_{2} \mathrm{MVP}_{128}-b-\mathrm{PEO}_{477}\right)$. As a start, dynamic light scattering (DLS) experiments were performed to determine the PMCs. The results of SBFP2 with $\mathrm{P}_{2} \mathrm{MVP}_{41}-b-\mathrm{PEO}_{205}$ and $\mathrm{P}_{2} \mathrm{MVP}_{128}-b-\mathrm{PEO}_{477}$ are shown in Figure 3. The highest concentration of micelles is found at the maximum of the scattered light intensity. For SBFP2, PMCs are found at $F^{+}$values of 0.75 and 0.70 for $\mathrm{P}_{2} \mathrm{MVP}_{41}-b-\mathrm{PEO}_{205}$ and $\mathrm{P}_{2} \mathrm{MVP}_{128}-b-\mathrm{PEO}_{477}$, respectively (Figure 3 and Table 1). Similar DLS experiments were performed on the other six FPs with both diblock copolymers (Figure S2) and their respective PMCs are listed in Table 1. For all FPs and with both diblock copolymers, optimal $F^{+}$values ranging between 0.60 and 0.75 were found. Samples with this optimal composition were used in all other spectroscopic analyses: fluorescence correlation spectroscopy (FCS), circular dichroism (CD), and steady-state fluorescence spectroscopy.

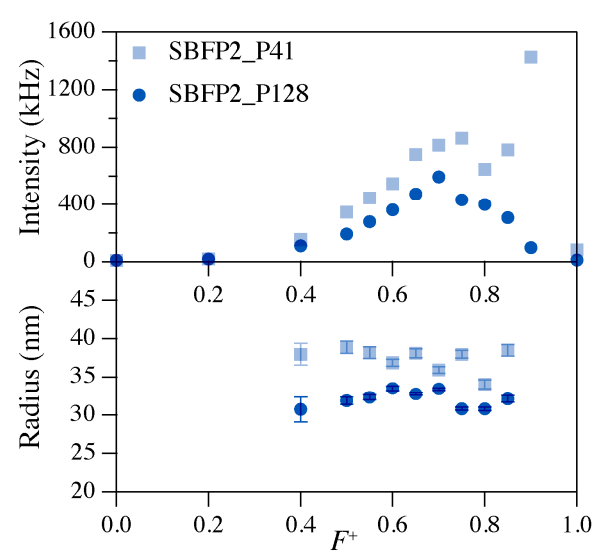

Figure 3. DLS results of micellar compositions of SBFP2 mixed with $\mathrm{P}_{2} \mathrm{MVP}_{41}-b-\mathrm{PEO}_{205}$ (P41, light blue colored blocks) or $\mathrm{P}_{2} \mathrm{MVP}_{128}-b-\mathrm{PEO}_{477}$ (P128, dark blue colored circles). The protein concentration was kept constant at $1.0 \mu \mathrm{M}$. Top graph shows scattered intensity as a function of the $F^{+}$composition, and bottom graph shows the hydrodynamic radius as a function of the $F^{+}$composition. Error bars reflect the distribution of radii in one experiment. DLS composition results of the six other fluorescent proteins are given in Figure S2.

The fluctuations of the scattered light intensities were used to calculate the hydrodynamic radii of the C3Ms. For all seven FPs, the hydrodynamic radii of the C3Ms are quite constant over a relatively wide range of $F^{+}$compositions $\left(0.40<F^{+}<0.80\right.$, Figure 3 and Figure S2). In general, radii of the formed C3Ms vary between 30 and $38 \mathrm{~nm}$, except for C3Ms formed with $\mathrm{mKO} 2$, which are somewhat smaller with radii of about $27 \mathrm{~nm}$ (Table 1).

\subsection{Encapsulation Efficiency}

Next to DLS, FCS can be used for the determination of PMC values [18]. An advantage of FCS is that it gives, amongst other parameters, the average number of fluorescent particles in the confocal volume ( $N$, Equation (2)). In this study, the fluorescent particles observed are free FPs and C3Ms with multiple FPs encapsulated. We quantified the number of free FPs before addition of polymers $\left(N_{\text {before}}\right)$ and of fluorescent particles after addition of polymers $\left(N_{\text {after }}\right)$, and expressed the encapsulation efficiency per FP according to the following relation: $E_{\text {encap }}=1-\left(N_{\text {after }} / N_{\text {before }}\right)$. The encapsulation efficiencies per FP are shown in Figure 4 and the corresponding graph with the number of fluorescent particles is shown in Figure S3. FCS was not performed on samples containing SBFP2 because no suitable excitation source for this FP was available on the used confocal microscope.

For all avFPs, the encapsulation efficiencies are almost $100 \%$ with both diblock copolymers, meaning that virtually all protein molecules are packed in C3Ms. However, we observed lower 
encapsulation efficiencies for anFPs ( $50 \%$ to $75 \%$, see Figure 4), which implicates that, for these FPs, more protein molecules remain free in solution (Figure S3).

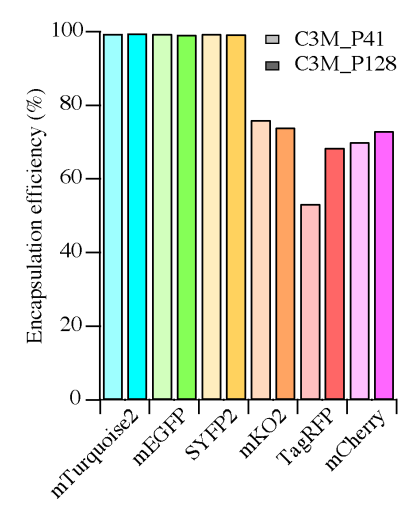

Figure 4. Encapsulation efficiencies of the different fluorescent proteins studied (except SBFP2) at their respective PMCs with $\mathrm{P}_{2} \mathrm{MVP}_{41}-b-\mathrm{PEO}_{205}$ (C3M_P41, light colored bars) and $\mathrm{P} 2 \mathrm{MVP} \mathrm{P}_{128}-b-\mathrm{PEO}_{477}$ (C3M_P128, dark colored bars) determined using FCS. Efficiencies are calculated from the average number of fluorescent particles observed in the confocal volume ( $N$ in Equation (2) and Figure S3).

\subsection{Fluorescence Properties}

Previously, we have shown that encapsulation of EGFP and mEGFP resulted in different spectral properties compared to that of the proteins free in solution [19]. The spectral properties of EGFP upon encapsulation do not changes more than that of mEGFP, which is due to the $\mathrm{p} K_{\mathrm{a}}$ shift of the chromophore of EGFP. To investigate if encapsulation changes the spectral properties of the FPs, absorption and fluorescence excitation and emission spectra for all FPs free in solution, as well as encapsulated in C3Ms were recorded (Figure 5 and Figure S4).

We observed that encapsulation of the FPs leads to minor differences in their absorption and fluorescence properties and these are dependent on the kind of FP and the type of polymer used. Figure 5H,I shows that, for SBFP2, both the absorption and the fluorescence intensity increases upon encapsulation. Encapsulation of mTurquoise2, mEGFP, and SYFP2 resulted in a decrease of the fluorescence intensity, whereas the absorption remained the same. Both the absorption and fluorescence intensity decreases upon encapsulation of TagRFP. For mCherry, the fluorescence intensity increases and the absorption and excitation maxima become blue-shifted upon encapsulation (for absorption spectra see Figure S4). The absorption and fluorescence results were combined in the determination of relative quantum yields of FPs encapsulated in C3Ms (Equation (4) and Table 2). Table 2 shows that the quantum yield of SBFP2 does not change; that of mCherry increases; and that of the other FPs decreases upon encapsulation.

To address if the observed spectral changes are due to a pH-related phenomenon, fluorescence excitation and emission spectra at different $\mathrm{pH}$ values were acquired of all FPs free in solution (see Figure S5). SBFP2, mEGFP, SYFP2, and $\mathrm{mKO} 2$ have a $\mathrm{p} K_{\mathrm{a}}$ of 5.5-6.0 and show a large decrease in their fluorescence intensity at $\mathrm{pH}$ 5. For the latter three proteins, this effect is caused by protonation of the phenolic oxygen of the chromophore (Figure 1D-F and Figure S5C-E). mCherry shows a stronger susceptibility to changes in $\mathrm{pH}$ (Figure S5G): at increasing $\mathrm{pH}$ values (from $\mathrm{pH} 5$ to 10), the spectra are blue-shifted and the fluorescence intensity increases. These changes resemble the changes observed upon encapsulation of mCherry.

The only two FPs showing no significant effect upon changes of $\mathrm{pH}$ are mTurquoise 2 and TagRFP, which can be explained by their rather low $\mathrm{p} K_{\mathrm{a}}$ values $\left(\mathrm{p} K_{\mathrm{a}} \sim 3.5\right.$, see Figure S5F). It is therefore remarkable that the fluorescence intensity of TagRFP decreases about $40 \%$ upon encapsulation compared to the free protein (Figure $5 \mathrm{H}$ ), even though the encapsulation efficiency is about $60 \%$ (Figure 4). This suggests that the fluorescence of TagRFP is highly affected upon encapsulation. 
In solution, TagRFP tends to dimerize with a $K_{\mathrm{D}}$ of $38.4 \mu \mathrm{M}$ [36]. Assuming a protein concentration of about $10 \mathrm{mM}$ in the C3Ms, this implies that TagRFP associates into dimers or tetramers inside C3Ms, which might cause the drastic decrease of quantum yield of the chromophore upon encapsulation.

Next to these differences between the FPs, we also observed an effect depending on the length of diblock copolymer used: if the fluorescence increases upon encapsulation, the increase is larger with the longer polymer $\left(\mathrm{P}_{2} \mathrm{MVP}_{128}-b-\mathrm{PEO}_{477}\right)$ than with the shorter one ( $\left.\mathrm{P} 2 \mathrm{MVP}_{41}-b-\mathrm{PEO}_{205}\right)$. Conversely, if the fluorescence decreases upon encapsulation, the decrease is larger with the shorter polymer than with the longer one, except for TagRFP (Figure 5H). This dependency, however, is not observed in the absorption spectra (Figure 5I).
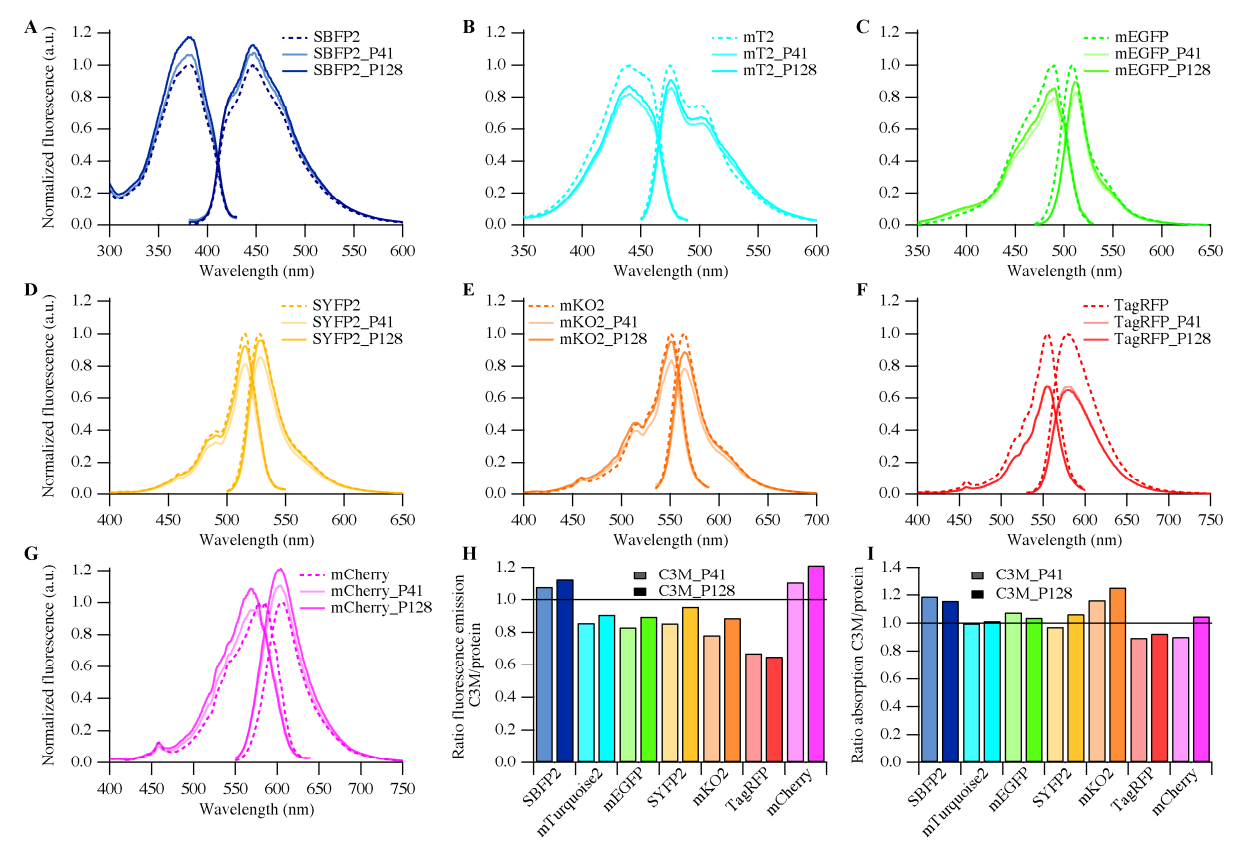

Figure 5. Fluorescence excitation and emission spectra of (A) SBFP2; (B) mTurqouise2; (C) mEGFP; (D) SYFP2; (E) mKO2; (F) TagRFP and (G) mCherry for protein free in solution (dashed lines) and encapsulated proteins in C3Ms at their respective PMCs with $\mathrm{P}_{2 M V P}-b-\mathrm{PEO}_{205}$ (P41, solid light colored lines) and $\mathrm{P}_{2} \mathrm{MVP}_{128}-b-\mathrm{PEO}_{477}$ (P128, solid dark colored lines). The spectra are normalized to those of the free proteins measured at identical conditions. (H) Ratio of fluorescence emission; and (I) ratio of absorption of encapsulated protein (C3M) to that of protein free in solution (values for mCherry are taken from the maxima). Ratios for all proteins were measured at the PMC with $\mathrm{P}_{2} \mathrm{MVP}_{41}-b-\mathrm{PEO}_{205}$ (C3M_P41, light colored bars) and P2MVP $128-b-\mathrm{PEO}_{477}$ (C3M_P128, dark colored bars). The corresponding absorption spectra are displayed in Figure S4.

Table 2. Quantum yields of the encapsulated proteins in C3Ms with $\mathrm{P}_{2} \mathrm{MVP}_{41}-b-\mathrm{PEO}_{205}$ (C3M_P41) and $\mathrm{P}_{2 \mathrm{MVP}}{ }_{128}-b-\mathrm{PEO}_{477}\left(\mathrm{C} 3 \mathrm{M} \_\mathrm{P} 128\right)$ compared to those of the proteins free in solution according to Equation (4).

\begin{tabular}{cccc}
\hline Fluorescent Protein Variant & Free Protein & C3M_P41 & C3M_P128 \\
\hline SBFP2 & 0.47 & 0.47 & 0.46 \\
mTurquoise2 & 0.93 & 0.84 & 0.88 \\
mEGFP & 0.60 & 0.44 & 0.50 \\
SYFP2 & 0.68 & 0.60 & 0.62 \\
mKO2 & 0.62 & 0.41 & 0.45 \\
TagRFP & 0.48 & 0.33 & 0.25 \\
mCherry & 0.22 & 0.25 & 0.24 \\
\hline
\end{tabular}




\subsection{Secondary Structure}

To investigate whether the differences in encapsulation efficiencies are due to structural perturbations of the FPs, far-UV circular dichroism (CD) experiments were performed. Figure 6 shows CD spectra of all seven FPs free in solution and encapsulated with $\mathrm{P}_{2} \mathrm{MVP}_{41}-b-\mathrm{PEO}_{205}$ or with $\mathrm{P}_{2} \mathrm{MVP}_{128}-b-\mathrm{PEO}_{477}$. The CD spectra of the FPs are not affected by the increase in $\mathrm{pH}$, as the CD spectra at $\mathrm{pH} 9.0$ or 10.0 do not show any differences compared to those at $\mathrm{pH} 7.0$ [37].

For all FPs, a negative mean residue ellipticity near $220 \mathrm{~nm}$ was observed, which is in good agreement with the prominent $\beta$-barrel architecture of these proteins (Figure 1A) and in line with previous observations $[19,38]$. The spectrum of $\mathrm{mKO} 2$, however, resembles more a $\alpha$-helical architecture with two negative peaks near 210 and $220 \mathrm{~nm}[39,40]$.

The CD spectra of the four avFPs free in solution are quite similar in shape (Figure 6A). The CD spectra of the $a n$ FPs are remarkably different compared to those of the $a v$ FPs (SBFP2 was taken as a representative reference, see Figure 6B). To our knowledge, these differences have not been reported before, and are further addressed in Section 3.2.

Upon encapsulation of the FPs, the CD spectra alter to a greater or lesser extent compared to that of the proteins free in solution, especially in the range where the spectra switch ellipticity ("zero crossing", between 205 and $215 \mathrm{~nm}$ ). For the encapsulated avFPs and for encapsulated mKO2, the zero crossing shifts to higher wavelength compared to that of the respective free FPs (Figure 6C-G). On the other hand, the zero crossings of encapsulated TagRFP and mCherry change to lower wavelengths compared to that of the free proteins (Figure 6H,I). In general, the zero crossings of all encapsulated FPs shift to $\pm 210 \mathrm{~nm}$. Apart from the zero crossings, the changes upon encapsulation of mTurquoise2, SYFP2, and $\mathrm{mKO} 2$ are moderate. More pronounced deviations in CD spectra after encapsulation are observed for SBFP2, mEGFP, and TagRFP. The largest change, however, can be observed for mCherry, with a significant positive decrease and a negative increase in ellipticity around 200 and $220 \mathrm{~nm}$, respectively (Figure 6I).

\section{Discussion}

Previously, we found that the encapsulation of EGFP in C3Ms stimulates protein dimerization and changes the spectral properties of the EGFP chromophore [19]. Because mEGFP mainly remains monomeric in the densely packed C3Ms, encapsulation of this protein hardly affects its spectral properties. In this work, we studied the encapsulation of four av FPs and three an FPs in C3Ms. All investigated FPs were successfully encapsulated using two diblock copolymers ( $\mathrm{P}_{2} \mathrm{MVP}_{41}-b-\mathrm{PEO}_{205}$ and $\left.\mathrm{P}_{2} \mathrm{MVP}_{128}-b-\mathrm{PEO}_{477}\right)$ with $F^{+}$values ranging between 0.60 and 0.80 . For strong polyelectrolytes, stoichiometric $\mathrm{C} 3 \mathrm{M}$ systems are formed at a $F^{+}$value of 0.50 [41]. Proteins, however, are weak polyelectrolytes and therefore their charge may change upon interaction with the diblock copolymer. Moreover, coacervation between polymer and protein does not necessarily arise from the overall charge of the protein, but rather from specific charge patches on the protein surface [42]. Both effects can even lead to coacervation between similarly charged proteins and polyelectrolytes [43-46].

\subsection{Encapsulation Efficiency}

The encapsulation efficiencies of avFPs (mEGFP, SBFP2, SYFP2 and mTurquoise2) were almost $100 \%$, whereas those of anFPs (mKO2, TagRFP and mCherry) varied between $50 \%$ and $75 \%$. This implicates that the interactions between the an FPs and the diblock copolymers to form C3Ms are less favorable. The formation of C3Ms requires an interaction between the FPs and the polymers, which can be dependent on the surface charge distribution and/or the shape of the protein. For the investigation of the presence of specific charge patches on the protein surface, we determined the surface potential distribution of the FPs on the acquired protein structures. For this, homology modeling was used to obtain the protein structures of SBFP2, SYFP2, and mKO2, next to the crystal structures of mTurquoise2, mEGFP, TagRFP, and mCherry. In Figure 7, the surface potentials of the FPs 
are visualized at the $\mathrm{pH}$ value at which they were encapsulated. All avFPs share a negative surface patch, as displayed on the side view at $90^{\circ}$, with an expansion to half of the molecule displayed in the side view at $180^{\circ}$. The amino acid residues with negative charge belonging to this patch are located on $\beta$-strands 1 and 2 . The three anFPs do not contain a similar negative patch displayed on the side view at $90^{\circ}$, as observed for $a v F P s$. Negative patches for mKO2 and TagRFP are mainly present in the side view at $0^{\circ}$. For TagRFP, the amino acid residues with negative charge are more distributed over the entire protein surface than for the other proteins. For mCherry, there is not a side entirely filled with negatively charged amino acid residues. It is key for the positively charged polyelectrolyte to bind to a local negative charge patch on the protein while minimizing the repulsive effect arising from the positively charged amino acid residues. Therefore, the interactions between the diblock copolymers and $\mathrm{mKO} 2$, TagRFP, and mCherry might not be optimal, thus affecting their encapsulation efficiencies.
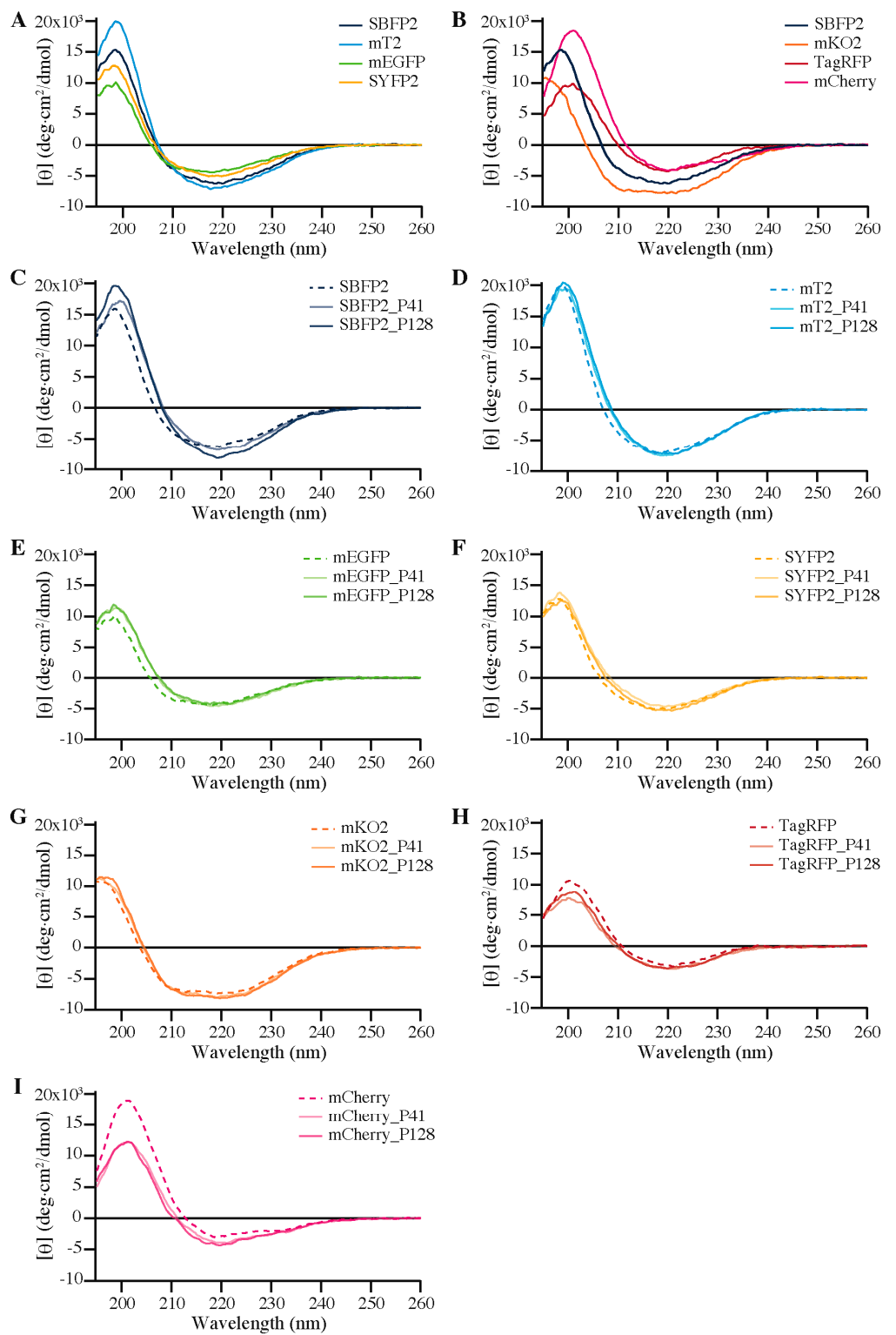

Figure 6. Comparison of the far-UV CD spectra of the free proteins (A) avFPs; (B) anFPs with SBFP2 as a reference representing the avFPs. Far-UV CD spectra of (C) SBFP2; (D) mTurquoise2 (mT2); (E) mEGFP; (F) SYFP2; (G) mKO2; (H) TagRFP and (I) mCherry free in solution (dashed line) and encapsulated with $\mathrm{P}_{2} \mathrm{MVP}_{41}-b-\mathrm{PEO}_{205}$ (P41, solid light colored line) and $\mathrm{P}_{2} \mathrm{MVP}_{128}-b-\mathrm{PEO}_{477}(\mathrm{P} 128$, solid dark colored line). The corresponding high tension signals are shown in Figure S6. 


\subsection{Elliptical Symmetry of FP Barrels}

During this study, we uncovered clear differences in the far-UV CD spectra between $a v$ FPs and anFPs free in solution (Figure 6B). It is well known that all FPs share a similar 11-stranded $\beta$-barrel fold (Figure 1A). However, it is hardly reported in the literature that the elliptical symmetry between avFPs and anFPs is diverse [47]. Figure 8 shows the ribbon structures of the studied FPs in three different orientations: the broad side, the narrow side, and the top. From the top views, it is clear that the barrels of the FPs are not completely round, but form elliptic cylinders. The avFPs are rounder than the anFPs, which is depicted by the difference in aspect ratio: $\sim 0.85$ for the $a v$ FPs and $\sim 0.74$ for the anFPs. Especially $\mathrm{mKO} 2$ is the most "squeezed" of the an FPs. We hypothesize that these differences are the cause for the observed differences in the far-UV CD spectra. Micsonai et al. reported that CD spectra are influenced, among others, by degree of twist and distortion of the $\beta$-sheets [48]. The variance in the elliptical symmetry is another apparent difference between avFPs and anFPs, and could also be influencing their encapsulation efficiencies.

\subsection{Biophysical Properties of Encapsulated Proteins}

Encapsulation of the avFPs hardly influenced their secondary structural properties and only minor changes in absorption and emission characteristics were observed. All avFPs bear the A206K mutation, which favors their monomeric state. This supports that the minor spectral changes observed are caused by the electrostatic interactions between the polymers and the protein surfaces of these FPs.

All anFPs are found as tetramers in their hosts $[9,10,26]$. The an FPs used here are all modified to enhance their tendency to remain monomeric. In literature, this tendency is expressed in terms of dissociation constants and "monomeric quality" (see Table S2). Previously, we calculated the number of EGFP molecules present in a C3M to be around 400, yielding a local protein concentration of about $10 \mathrm{mM}[18,19]$. Since the FPs used in this study form C3Ms with PMCs $(\sim 0.65)$ and radii $(\sim 34 \mathrm{~nm})$ similar to EGFP-C3Ms, it is a reasonable assumption that the protein concentration in the various FP-C3Ms is about the same. Hence, we expect that mCherry with a monomeric quality of $95 \%$ remains mostly monomeric upon encapsulation. However, $\mathrm{mKO} 2$ and TagRFP with monomeric qualities of $68 \%$ and $58 \%$, respectively, and a dissociation constant of $0.038 \mathrm{mM}$ for TagRFP, will likely form oligomers in the C3Ms (Table S2). This oligomerization causes the large decrease in quantum yield of the encapsulated forms of $\mathrm{mKO} 2$ and TagRFP (Table 2).

For encapsulated mCherry, the absorption spectrum changes according to a $\mathrm{p} K_{\mathrm{a}}$ shift of its chromophore (Figure S4). For EGFP it was proposed that the $\mathrm{p} K_{\mathrm{a}}$ shift of its chromophore is caused by a reorientation of Glu222 due to the dimerization of EGPF in C3Ms [19]. For free mCherry, the equivalent Glu215 is also linked to the $\mathrm{pH}$-dependent spectral shifts (Figure S5G) [27]. If mCherry, however, remains monomeric in the C3Ms, the reorientation of Glu215 can only occur due to the interaction between protein and polymer.

\subsection{Future Research}

We show that encapsulation of structurally similar FPs in C3Ms is dependent on the origin of the FPs and can give rise to different encapsulation efficiencies. Moreover, the spectral and structural perturbations observed are dependent on the kind of FP and the type of polymer used. In future research, we plan to investigate the stability and dynamics of encapsulated FPs. This can be accomplished by mixing two appropriate FPs using FRET as a readout. Some requirements should be considered choosing an optimal FP FRET-pair: First, use fluorescent proteins with similar encapsulation efficiencies. Second, use FPs that show minor changes in their absorption and fluorescence properties upon encapsulation into the C3Ms. Third, use the diblock copolymer which has the least effect on the fluorescence properties of the FPs. According to the present results, the ideal partners of an FRET-pair in C3Ms would be mTurquoise2 and SYFP2 in combination with P2MVP $128-b-\mathrm{PEO}_{477}$. 


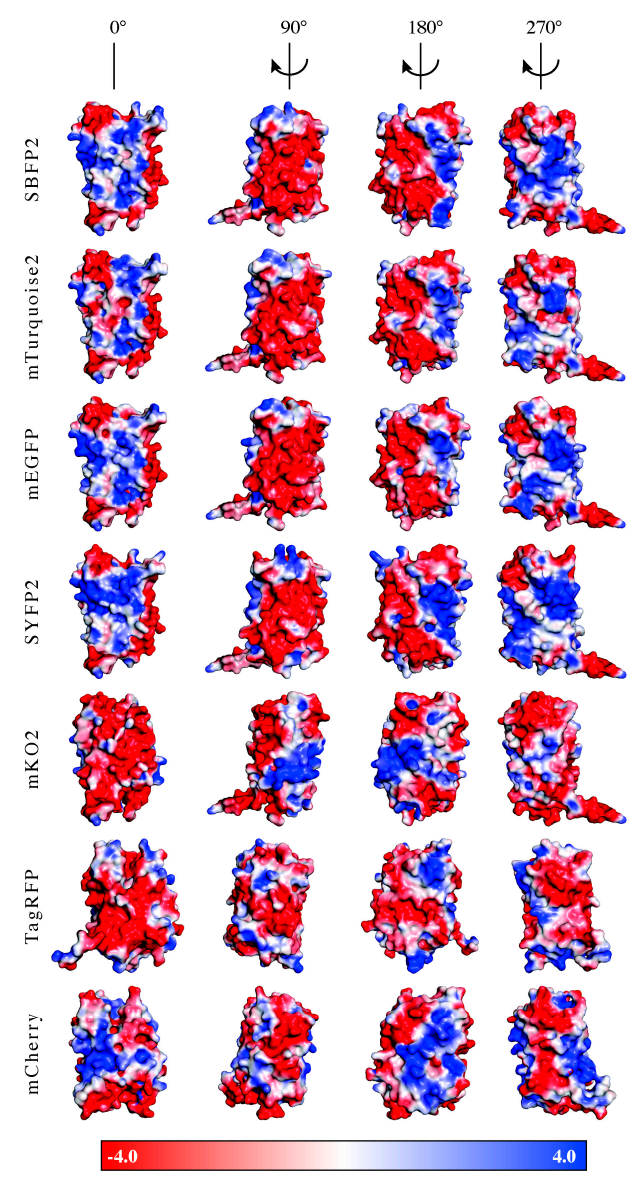

Figure 7. Comparison of the seven investigated proteins' electrostatic potentials (in $\left.k_{B} T / e_{c}\right)$ at the molecular surface in four different orientations: SBFP2, mTurquoise2, mEGFP, SYFP2, mKO2, TagRFP, and mCherry. Color surface overlay denotes electrostatic potential according to the scale shown: Red, negative potential; white, neutral; and blue, positive potential. Figure created by solution of the Poisson-Boltzmann equation using the default parameters of the PyMOL APBS (Adaptive Poisson-Boltzmann Solver) Tools plugin [49,50] in MacPyMOL 1.4 [51].

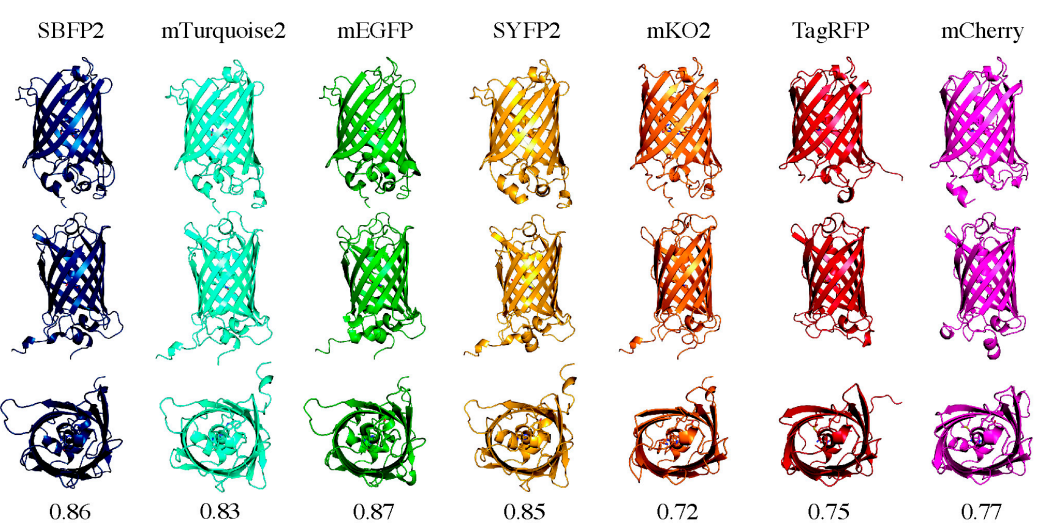

Figure 8. Ribbon structures of the seven FPs in three different orientations. At the top, the broad side; in the middle, the narrow side; and at the bottom, the "top" (the base containing both termini) of the proteins is shown. Numbers indicate the aspect ratio between the narrow and the broad side of the proteins. 


\section{Materials and Methods}

\subsection{Materials}

Poly(2-vinyl-pyridinium) $)_{\mathrm{n}}-b$-poly(ethylene-oxide $)_{\mathrm{m}}\left(\mathrm{P} 2 \mathrm{VP} \mathrm{n}-b-\mathrm{PEO}_{\mathrm{m}}\right)$ with different chain lengths was quaternized: P2VP $41-b-\mathrm{PEO}_{205}$ (Polymer Source Inc., Dorval, Quebec, Canada, $M_{w} / M_{n}=1.05$, $M_{n}=13.3 \mathrm{~kg} / \mathrm{mol}$ ) and $\mathrm{P}_{2} \mathrm{VP}_{128}-b-\mathrm{PEO}_{477}$ (Polymer Source Inc., Canada, $M_{w} / M_{n}=1.10$, $\left.M_{n}=34.5 \mathrm{~kg} / \mathrm{mol}\right)$, following a procedure described elsewhere [18]. For P2MVP $41-b-\mathrm{PEO}_{205}$ $\left(M_{n}=18.6 \mathrm{~kg} / \mathrm{mol}\right)$ and for $\mathrm{P}_{2} \mathrm{MVP}_{128}-b-\mathrm{PEO}_{477}\left(M_{n}=50.8 \mathrm{~kg} / \mathrm{mol}\right)$ a final degree of quaternization of approximately $80 \%$ and $87 \%$ was obtained, respectively. Stock solutions of $\mathrm{P}_{2} \mathrm{MVP}_{41}-b-\mathrm{PEO}_{205}(51 \mu \mathrm{M})$ and $\mathrm{P}_{2} \mathrm{MVP}_{128}-b-\mathrm{PEO}_{477}(50 \mu \mathrm{M})$ were prepared by dissolving the polymers in $10 \mathrm{mM}$ borate buffer ( $\mathrm{pH}$ 9.0) and stored at $-20^{\circ} \mathrm{C}$. All solutions were filtered through $0.20 \mu \mathrm{m}$ polyethersulfone membrane syringe filters (Advanced Microdevices Pvt. Ltd., Ambala Cantt, India). All other chemicals were from commercial sources and of the purest grade available.

\subsection{Protein Production}

The cDNA's coding for mTurquoise2, SYFP2-His, and mCherry were cloned into the bacterial expression vector pTYB12 (New England Biolabs, Ipswich, MA, USA) to generate FP fusions with a chitin-binding domain and an intein [52-54]. The cDNA's of SBFP2, mEGFP, mKO2, and TagRFP in pRSETb vectors were kindly provided by Dr. J. Goedhart, University of Amsterdam [22-24]. For protein production, E. coli BL21 cells were used. Details on protein production and purification are described elsewhere [19]. FPs without the chitin-binding domain were acquired after on-column cleavage of mTurquoise2, SYFP2-His, and mCherry. The other FPs, i.e., SBFP2, mEGFP, mKO2, and TagRFP still contained the His-tag after purification. Purified protein samples were stored in $10 \mathrm{mM}$ borate buffer ( $\mathrm{pH} 9.0)$ at $-20{ }^{\circ} \mathrm{C}$.

Protein concentrations were determined with a Pierce BCA protein assay (Pierce Biotechnology, Rockford, IL, USA), using a bovine serum albumin standard as a reference. The purity of the FPs was checked by SDS-PAGE.

\subsection{Modeling}

Homology models were built from existing crystal structures using SWISS-MODEL [55-58]. Table 3 shows the proteins used in this paper and their corresponding PDBs. Table 4 shows the proteins used in this paper and their respective templates used for the homology modeling. The chromophores were placed in the model structure at the same position and orientation as the chromophore in the template structure. Pairwise sequence alignments of the FPs are listed in Figures S7-S13. Because some $\mathrm{N}$ - and C-termini were missing in the created homology models (for SBFP2, mEGFP, and SYFP2), these termini were modeled manually using the PDB entry 3ZTF as a template. The A206K mutants were created by mutagenesis of Ala206 into Lys206 in PDB entries 4EUL and 3ZTF to construct mEGFP and mTurquoise2, respectively.

Table 3. PDB structures used for the proteins studied in this research listed with their corresponding figures, sequence identities (\% ID) and references.

\begin{tabular}{ccccc}
\hline Protein & PDB Entry & Figure & \% ID & Reference \\
\hline mTurquoise2 & 3ZTF & S8 & 99.57 & Goedhart, et al. [23] \\
mEGFP & 4EUL & S9 & 99.56 & Arpino, et al. [29] \\
TagRFP & 3M22 & S12 & 100.00 & Subach, et al. [59] \\
mCherry & 2H5Q & S13 & 100.00 & Shu, et al. [27] \\
\hline
\end{tabular}


Table 4. Homology models built from PDB entry templates for the proteins studied in this research listed with their corresponding figures, sequence identities (\% ID) and references.

\begin{tabular}{ccccc}
\hline Protein & PDB Entry & Figure & \% ID & Reference \\
\hline SBFP2 & 1BFP & S7 & 96.44 & Wachter, et al. [60] \\
SYFP2 & 1MYW & S10 & 99.12 & Rekas, et al. [61] \\
mKO2 & 2ZMU & S11 & 95.31 & Kikuchi, et al. [62] \\
\hline
\end{tabular}

\subsection{C3M Preparation}

Encapsulation of FPs with polymers was achieved by first diluting the FP stock solution in $10 \mathrm{mM}$ borate buffer at $\mathrm{pH} 9.0$ for SBFP2, mTurquoise2, mEGFP, SYFP2, mKO2, and mCherry; and at $\mathrm{pH} 10.0$ for TagRFP to the desired concentration, followed by addition of the polymer. After mixing, samples were stored at room temperature for $24 \mathrm{~h}$ before measuring. All experiments were performed in $10 \mathrm{mM}$ borate buffer at the encapsulation $\mathrm{pH}$.

\subsection{Dynamic Light Scattering (DLS)}

DLS measurements were performed on an ALV instrument equipped with a $300 \mathrm{~mW}$ Cobolt Samba-300 DPSS laser operating at $660 \mathrm{~nm}$ and $100 \mathrm{~mW}$, and static and dynamic enhancer fiber optics for an ALV/High QE APD (high quantum efficiency avalanche photo diode) single photon detector connected to an ALV5000/60X0 External Correlator (ALV-Laser Vertriebsgesellschaft m-b.H., Langen, Germany). The detection angle $\theta$ was set at $90^{\circ}$ and all measurement were performed at room temperature.

DLS measures fluctuations in scattered light intensities caused by the diffusion of particles. The diffusion time of particles is dependent on their size: proteins diffuse faster than the encapsulated proteins in C3Ms. Furthermore, larger particles scatter more light, because the scattered light intensity is proportional to $R^{6}$, where $R$ is the particle radius. The formation of more C3Ms leads to higher light intensities, which results in a maximum in the scattered light intensity versus composition plot $\left(I \mathrm{vs} . \mathrm{F}^{+}\right)$. The composition at the maximum in scattered light intensity is denoted as the preferred micellar composition (PMC). For determination of the PMC, $500 \mu \mathrm{L}$ solutions with different polymer/protein compositions were prepared. The protein concentration was kept constant at $1 \mu \mathrm{M}$ for each composition. The amount of $\mathrm{P}_{2} \mathrm{MVP}_{41}-b-\mathrm{PEO}_{205}$ or $\mathrm{P}_{2} \mathrm{MVP}_{128}-b-\mathrm{PEO}_{477}$ was varied to obtain the desired values of $F^{+}$:

$$
F^{+}=\frac{\left[n_{+}\right]}{\left[n_{+}\right]+\left[n_{-}\right]}
$$

where $\left[n_{+}\right]=c_{+} N_{+}$refers to the total concentration of positively charged groups on the polymer and $\left[n_{-}\right]=c_{-} N_{-}$is the total concentration of negatively charged groups on the protein molecules. The number of charged groups on the diblock copolymer $\left(N_{+}\right)$taking the degree of quaternization into account, is +33.1 for $\mathrm{P}_{2} \mathrm{MVP}_{41}-b-\mathrm{PEO}_{205}$ and +112.0 for $\mathrm{P}_{2} \mathrm{MVP}_{128}-b-\mathrm{PEO}_{477}$, which is used to calculate $\left[n_{+}\right]$. The net charge of the proteins as a function of $\mathrm{pH}$ was calculated using the software package PROPKA $3.1[32,33]$. The charges of the native proteins at $\mathrm{pH} 9$ or $10\left(N_{-}\right)$are listed in Table 1 , which are used to calculate $\left[n_{-}\right]$.

\subsection{DLS Data Analysis}

DLS autocorrelation curves were generated from 10 intensity traces and averaged. The CUMULANT method $[63,64]$ was used to analyze the mean apparent hydrodynamic radius $\left(R_{\mathrm{h}}\right)$ as:

$$
R_{\mathrm{h}}=\frac{k T q^{2}}{6 \pi \eta \Gamma}
$$

where $q$ is the scattering vector, $k$ is the Boltzmann constant, $T$ is the absolute temperature, $n$ is the viscosity of the solvent, and $\Gamma$ is the measured average decay rate of the correlation function. The 
CONTIN method $[65,66]$ is used to analyze the distribution of the radii of the C3Ms. The data were analyzed with the AfterALV program (AfterALV 1.0d, Dullware, The Netherlands).

\subsection{Fluorescence Correlation Spectroscopy (FCS)}

FCS was performed on a Leica TCS SP8 X SMD system equipped with a $63 \times 1.20$ NA (numeric aperture) water immersion objective with coverslip thickness correction collar. Samples with FPs were excited using a diode laser (emits at $440 \mathrm{~nm}$ ) or a super continuum laser (emits a continuous spectrum from 470 to $670 \mathrm{~nm}$ ). The lasers were set at a pulsed frequency of $40 \mathrm{MHz}$. The size-adjustable pinhole was set at $70 \mu \mathrm{m}$ for all measurements. Fluorescence emission was detected using bandpass-adjustable spectral filters. In Table 5 the used laser lines and range of the spectral filters are given per fluorescent protein. Fluorescence was recorded via the internal hybrid detector, which was coupled to a PicoHarp 300 TCSPC module (PicoQuant, Berlin, Germany). With this system, it was not possible to measure SBFP2, because its excitation maximum is below $440 \mathrm{~nm}$.

Table 5. Settings for the FCS measurements per studied protein.

\begin{tabular}{ccc}
\hline Protein & Laser Line $(\mathbf{n m})$ & Spectral Filter $(\mathbf{n m})$ \\
\hline mTurquoise2 & 440 & $475-500$ \\
mEGFP & 488 & $495-525$ \\
SYFP2 & 514 & $520-550$ \\
mKO2 & 550 & $650-600$ \\
TagRFP and mCherry & 561 & $575-610$ \\
\hline
\end{tabular}

Rhodamine $110\left(D=4.3 \times 10^{-10} \mathrm{~m}^{2} \mathrm{~s}^{-1}\right)$ was used to calibrate the confocal volume of the setup. A diffusion time of $18 \mu$ s and a structural parameter $\left(a\right.$, expressed as $\left.\left(\omega_{x y} / \omega_{z}\right)\right)$ between 5 and 10 were obtained, resulting in a confocal volume of approximately $0.2 \mathrm{fL}$. Measurements were performed in a $\mu$-Slide 8-wells chambered coverslip (Ibidi ${ }^{\circledR}$ ).

Samples with concentrations of $1 \mu \mathrm{M}$ FP were measured free in buffered solution as well as encapsulated with $\mathrm{P}_{2} \mathrm{MVP}_{41}-b-\mathrm{PEO}_{205}$ or $\mathrm{P}_{2} \mathrm{MVP}_{128}-b-\mathrm{PEO}_{477}$ at their respective PMCs. For each sample, 5 fluorescence intensity fluctuation traces of $30 \mathrm{~s}$ each were collected. All measurements were performed at room temperature.

\subsection{FCS Data Analysis}

For the FCS data analysis, the FFS-data processor version 2.3 (Scientific Software Technologies Software Centre, Minsk, Belarus) was used [67]. The equation used to fit translational data, which includes triplet state, is as follows [68]:

$$
G(t)=1+\frac{1}{\langle N\rangle}\left(1+\frac{F_{\text {trip }}}{1-F_{\text {trip }}} e^{\frac{-\tau}{T_{\text {trip }}}}\right) \sum_{i=1}^{n} \frac{F_{i}}{\left(1+\left(\frac{t}{\tau_{\text {diff }, \mathrm{i}}}\right)\right) \sqrt{1+\left(\frac{\omega_{\text {xy }}}{\omega_{\mathrm{z}}}\right)^{2}\left(\frac{t}{\tau_{\text {diff }, \mathrm{i}}}\right)}}
$$

where $\langle N\rangle$ represents the average number of fluorescent particles in the confocal volume. The exponential term describes the triplet state behavior of the molecule, in which $F_{\text {trip }}$ is the fraction of molecules in the triplet state and $T_{\text {trip }}$ is the average time a molecule resides in the triplet state. The last part of the equation describes the diffusion behavior of the molecules, where $F_{i}$ is the fraction of species $i, \tau_{\text {diff, }}$ is the diffusion time of species $i, \omega_{\mathrm{xy}}$ and $\omega_{\mathrm{z}}$ are the equatorial and axial radii of the detection volume, respectively. Equation (3) was used to obtain $\langle N\rangle$ for the different samples.

\subsection{Steady-State Fluorescence Spectroscopy}

Fluorescence excitation and emission spectra were measured using a Cary Eclipse spectrofluorimeter (Varian). Excitation and emission slits were set to yield bandwidths of $5 \mathrm{~nm}$. 
All measurements were performed at $20^{\circ} \mathrm{C}$. Samples with concentrations of $1 \mu \mathrm{M}$ FP were measured free in buffered solution as well as encapsulated with $\mathrm{P}_{2} \mathrm{MVP}_{41}-b-\mathrm{PEO}_{205}$ or $\mathrm{P}_{2} \mathrm{MVP}_{128}-b-\mathrm{PEO}_{477}$ at their respective PMCs.

The relative quantum yields are calculated using the following equation [69]:

$$
\mathrm{QY}_{\mathrm{C} 3 \mathrm{M}}=\frac{\mathrm{QY}_{\mathrm{P}} \cdot \mathrm{FA}_{\mathrm{C} 3 \mathrm{M}} \cdot \mathrm{A}_{\mathrm{P}}}{\mathrm{FA}_{\mathrm{P}} \cdot \mathrm{A}_{\mathrm{C} 3 \mathrm{M}}}
$$

where QY represents the quantum yield, FA the integrated area under the corrected emission spectrum, and $\mathrm{A}$ the absorbance at the excitation wavelength. The subscripts $C 3 M$ and $P$ refer to the proteins in the C3Ms and the proteins free in solution, respectively.

\subsection{Circular Dichroism (CD)}

CD experiments were performed on a JASCO J-715 spectropolarimeter with a Jasco PTC 348 WI temperature controller set at $20^{\circ} \mathrm{C}$. The far-UV CD spectra $(195-260 \mathrm{~nm})$ were obtained from samples in a $0.3 \mathrm{~mL}$ quartz cuvette with an optical path length of $1 \mathrm{~mm}$. Thirty spectra, each recorded with a resolution of $1 \mathrm{~nm}$, a scan speed of $50 \mathrm{~nm} / \mathrm{min}$ and a response time of $1 \mathrm{~s}$, were accumulated and averaged. Samples with concentrations of $2.5 \mu \mathrm{M}$ FP were measured free in buffered solution as well as encapsulated with $\mathrm{P}_{2} \mathrm{MVP}_{41}-b-\mathrm{PEO}_{205}$ or $\mathrm{P}_{2} \mathrm{MVP}_{128}-b-\mathrm{PEO}_{477}$ at their respective PMC. The polymers did not show any $\mathrm{CD}$ signal over the measured range, therefore, buffer blank spectra, obtained at identical conditions, were subtracted.

\section{Conclusions}

We have studied the encapsulation efficiency of SBFP2, mTurquoise2, mEGFP, SYFP2, mKO2, TagRFP, and mCherry and determined their spectral and structural properties as protein free in solution and upon encapsulation with $\mathrm{P}_{2} \mathrm{MVP}_{41}-b-\mathrm{PEO}_{205}$ or $\mathrm{P}_{2} \mathrm{MVP}_{128}-b-\mathrm{PEO}_{477}$. This revealed that $a v \mathrm{FPs}$ are almost $100 \%$ encapsulated, while anFPs show encapsulation efficiencies ranging between $50 \%$ and $75 \%$. Upon encapsulation, all FPs show differences in spectral properties compared to their respective protein free in solution: the chromophores of SBFP2, $\mathrm{mKO} 2$, and mCherry are affected in their molar extinction coefficient and the chromophores of mTurquoise2, mEGFP, SYFP2, TagRFP, and mKO2 are affected in their fluorescence quantum yield. Only for mCherry, the changes in spectral properties upon encapsulation are similar to changes observed as a result of $\mathrm{pH}$ variation and are, therefore, related to a shift in the $\mathrm{p} K_{\mathrm{a}}$. Even though all FPs have an 11-stranded $\beta$-barrel fold, the CD spectra differ between $a v$ FPs and anFPs. This is most likely due to a different shape of the cylinders between the two groups of FPs, where the $\beta$-barrel structures of $a v$ FPs are almost round cylinders and that of anFPs elliptic ones. This variation in structure, together with the difference in charge distribution on FP surfaces, potentially causes the differences in encapsulation efficiency.

Supplementary Materials: References [70-74] appear in the Supplementary Materials. Supplementary materials can be found at www.mdpi.com/1422-0067/18/7/1557/s1.

Acknowledgments: Financial support from the Graduate School VLAG (Advanced Studies in Food Technology, Agro-Biotechnology, Nutrition and Health Sciences, Wageningen, The Netherlands) is gratefully acknowledged. The fluorescence correlation spectroscopy experiments were performed on a multimode confocal microscope supported by a NWO (Nederlandse Organisatie voor Wetenschappelijk Onderzoek) Middelgroot Investment Grant (721.011.004; Jan Willem Borst). We thank Dr. Joachim Goedhart (University of Amsterdam) for providing us with pRSETb vectors containing SBFP2, mEGFP, $\mathrm{mKO}$, and TagRFP.

Author Contributions: Antsje Nolles performed the experiments, analyzed the data, and wrote the manuscript; Adrie $\mathrm{H}$. Westphal assisted with CD analysis and data interpretation; Antsje Nolles, Mieke Kleijn, Willem J. H. van Berkel, and Jan Willem Borst designed the experiments; and Adrie H. Westphal, Mieke Kleijn, Willem J. H. van Berkel, and Jan Willem Borst contributed to the writing of the manuscript.

Conflicts of Interest: The authors declare no conflict of interest. The founding sponsors had no role in the design of the study; in the collection, analyses, or interpretation of data; in the writing of the manuscript, and in the decision to publish the results. 


\section{Abbreviations}

$\begin{array}{ll}a n \text { FP } & \text { Anthozoa fluorescent protein } \\ a v \text { FP } & \text { Aequorea victoria fluorescent protein } \\ \text { C3M } & \text { Complex coacervate core micelles } \\ \text { CD } & \text { Circular dichroism } \\ \text { DLS } & \text { Dynamic light scattering } \\ \text { EGFP } & \text { Enhanced green fluorescent protein } \\ \text { FCS } & \text { Fluorescence correlation spectroscopy } \\ \text { FP } & \text { Fluorescent protein } \\ \text { FRET } & \text { Förster resonance energy transfer } \\ \text { GFP } & \text { Green fluorescent protein } \\ \text { mEGFP } & \text { Monomeric enhanced green fluorescent protein } \\ \text { mKO2 } & \text { Monomeric Kusabira Orange 2 } \\ \text { P128 } & \text { P2MVP } 128-b \text {-PEO } \\ \text { P2MVP- } b \text {-PEO } & \text { poly(2-methyl-vinyl-pyridinium)- } b \text {-poly(ethylene-oxide) } \\ \text { P41 } & \text { P2MVP } 4 \text { - } b \text {-PEO } \\ \text { PDB } & \text { Protein Data Bank } \\ \text { PMC } & \text { Preferred micellar composition } \\ \text { SBFP2 } & \text { Strongly enhanced blue fluorescent protein } 2 \\ \text { SYFP2 } & \text { Strongly enhanced yellow fluorescent protein } 2 \\ \text { TagRFP } & \text { Tag red fluorescent protein }\end{array}$

\section{References}

1. Miyawaki, A.; Niino, Y. Molecular spies for bioimaging-Fluorescent protein-based probes. Mol. Cell 2015, 58, 632-643. [CrossRef] [PubMed]

2. Enterina, J.R.; Wu, L.; Campbell, R.E. Emerging fluorescent protein technologies. Curr. Opin. Chem. Biol. 2015, 27, 10-17. [CrossRef] [PubMed]

3. Zimmer, M. Green fluorescent protein (GFP): Applications, structure, and related photophysical behavior. Chem. Rev. 2002, 102, 759-781. [CrossRef] [PubMed]

4. Tsien, R.Y. The green fluorescent protein. Annu. Rev. Biochem. 1998, 67, 509-544. [CrossRef] [PubMed]

5. Shimomura, O.; Johnson, F.H.; Saiga, Y. Extraction, purification and properties of aequorin, a bioluminescent protein from the luminous hydromedusan, Aequorea. J. Cell. Comp. Physiol. 1962, 59, 223-239. [CrossRef] [PubMed]

6. Morise, H.; Shimomura, O.; Johnson, F.H.; Winant, J. Intermolecular energy transfer in the bioluminescent system of Aequorea. Biochemistry 1974, 13, 2656-2662. [CrossRef] [PubMed]

7. Prasher, D.C.; Eckenrode, V.K.; Ward, W.W.; Prendergast, F.G.; Cormier, M.J. Primary structure of the Aequorea victoria green-fluorescent protein. Gene 1992, 111, 229-233. [CrossRef]

8. Matz, M.V.; Fradkov, A.F.; Labas, Y.A.; Savitsky, A.P.; Zaraisky, A.G.; Markelov, M.L.; Lukyanov, S.A. Fluorescent proteins from nonbioluminescent Anthozoa species. Nat. Biotechnol. 1999, 17, 969-973. [CrossRef] [PubMed]

9. Karasawa, S.; Araki, T.; Nagai, T.; Mizuno, H.; Miyawaki, A. Cyan-emitting and orange-emitting fluorescent proteins as a donor/acceptor pair for fluorescence resonance energy transfer. Biochem. J. 2004, 381, 307-312. [CrossRef] [PubMed]

10. Merzlyak, E.M.; Goedhart, J.; Shcherbo, D.; Bulina, M.E.; Shcheglov, A.S.; Fradkov, A.F.; Gaintzeva, A.; Lukyanov, K.A.; Lukyanov, S.; Gadella, T.W.J.; et al. Bright monomeric red fluorescent protein with an extended fluorescence lifetime. Nat. Methods 2007, 4, 555-557. [CrossRef] [PubMed]

11. Shcherbo, D.; Murphy, C.S.; Ermakova, G.V.; Solovieva, E.A.; Chepurnykh, T.V.; Shcheglov, A.S.; Verkhusha, V.V.; Pletnev, V.Z.; Hazelwood, K.L.; Roche, P.M.; et al. Far-red fluorescent tags for protein imaging in living tissues. Biochem. J. 2009, 418, 567-574. [CrossRef] [PubMed]

12. Cranfill, P.J.; Sell, B.R.; Baird, M.A.; Allen, J.R.; Lavagnino, Z.; de Gruiter, H.M.; Kremers, G.J.; Davidson, M.W.; Ustione, A.; Piston, D.W. Quantitative assessment of fluorescent proteins. Nat. Methods 2016, 13, 557-562. [CrossRef] [PubMed] 
13. Shcherbo, D.; Merzlyak, E.M.; Chepurnykh, T.V.; Fradkov, A.F.; Ermakova, G.V.; Solovieva, E.A.; Lukyanov, K.A.; Bogdanova, E.A.; Zaraisky, A.G.; Lukyanov, S.; et al. Bright far-red fluorescent protein for whole-body imaging. Nat. Methods 2007, 4, 741-746. [CrossRef] [PubMed]

14. Chudakov, D.M.; Matz, M.V.; Lukyanov, S.; Lukyanov, K.A. Fluorescent proteins and their applications in imaging living cells and tissues. Physiol. Rev. 2010, 90, 1103-1163. [CrossRef] [PubMed]

15. Rhee, J.K.; Hovlid, M.; Fiedler, J.D.; Brown, S.D.; Manzenrieder, F.; Kitagishi, H.; Nycholat, C.; Paulson, J.C.; Finn, M.G. Colorful virus-like particles: Fluorescent protein packaging by the $Q \beta$ capsid. Biomacromolecules 2011, 12, 3977-3981. [CrossRef] [PubMed]

16. Seebeck, F.P.; Woycechowsky, K.J.; Zhuang, W.; Rabe, J.P.; Hilvert, D. A simple tagging system for protein encapsulation. J. Am. Chem. Soc. 2006, 128, 4516-4517. [CrossRef] [PubMed]

17. Minten, I.J.; Hendriks, L.J.; Nolte, R.J.; Cornelissen, J.J. Controlled encapsulation of multiple proteins in virus capsids. J. Am. Chem. Soc. 2009, 131, 17771-17773. [CrossRef] [PubMed]

18. Nolles, A.; Westphal, A.H.; de Hoop, J.A.; Fokkink, R.G.; Kleijn, J.M.; van Berkel, W.J.H.; Borst, J.W. Encapsulation of GFP in complex coacervate core micelles. Biomacromolecules 2015, 16, 1542-1549. [CrossRef] [PubMed]

19. Nolles, A.; van Dongen, N.J.E.; Westphal, A.H.; Visser, A.J.W.G.; Kleijn, J.M.; van Berkel, W.J.H.; Borst, J.W. Encapsulation into complex coacervate core micelles promotes EGFP dimerization. Phys. Chem. Chem. Phys. 2017, 19, 11380-11389. [CrossRef] [PubMed]

20. Zacharias, D.A.; Violin, J.D.; Newton, A.C.; Tsien, R.Y. Partitioning of lipid-modified monomeric GFPs into membrane microdomains of live cells. Science 2002, 296, 913-916. [CrossRef] [PubMed]

21. Sniegowski, J.A.; Phail, M.E.; Wachter, R.M. Maturation efficiency, trypsin sensitivity, and optical properties of Arg96, Glu222, and Gly67 variants of green fluorescent protein. Biochem. Biophys. Res. Commun. 2005, 332, 657-663. [CrossRef] [PubMed]

22. Kremers, G.J.; Goedhart, J.; van den Heuvel, D.J.; Gerritsen, H.C.; Gadella, T.W.J. Improved green and blue fluorescent proteins for expression in bacteria and mammalian cells. Biochemistry 2007, 46, 3775-3783. [CrossRef] [PubMed]

23. Goedhart, J.; von Stetten, D.; Noirclerc-Savoye, M.; Lelimousin, M.; Joosen, L.; Hink, M.A.; van Weeren, L.; Gadella, T.W.J.; Royant, A. Structure-guided evolution of cyan fluorescent proteins towards a quantum yield of 93\%. Nat. Commun. 2012, 3, 751. [CrossRef] [PubMed]

24. Kremers, G.J.; Goedhart, J.; van Munster, E.B.; Gadella, T.W.J. Cyan and yellow super fluorescent proteins with improved brightness, protein folding, and FRET Forster radius. Biochemistry 2006, 45, 6570-6580. [CrossRef] [PubMed]

25. Sakaue-Sawano, A.; Kurokawa, H.; Morimura, T.; Hanyu, A.; Hama, H.; Osawa, H.; Kashiwagi, S.; Fukami, K.; Miyata, T.; Miyoshi, H.; et al. Visualizing spatiotemporal dynamics of multicellular cell-cycle progression. Cell 2008, 132, 487-498. [CrossRef] [PubMed]

26. Shaner, N.C.; Campbell, R.E.; Steinbach, P.A.; Giepmans, B.N.; Palmer, A.E.; Tsien, R.Y. Improved monomeric red, orange and yellow fluorescent proteins derived from Discosoma sp. red fluorescent protein. Nat. Biotechnol. 2004, 22, 1567-1572. [CrossRef] [PubMed]

27. Shu, X.; Shaner, N.C.; Yarbrough, C.A.; Tsien, R.Y.; Remington, S.J. Novel chromophores and buried charges control color in mFruits. Biochemistry 2006, 45, 9639-9647. [CrossRef] [PubMed]

28. Albertazzi, L.; Arosio, D.; Marchetti, L.; Ricci, F.; Beltram, F. Quantitative FRET analysis with the EGFP-mCherry fluorescent protein pair. Photochem. Photobiol. 2009, 85, 287-297. [CrossRef] [PubMed]

29. Arpino, J.A.; Rizkallah, P.J.; Jones, D.D. Crystal structure of enhanced green fluorescent protein to 1.35 A resolution reveals alternative conformations for Glu222. PLoS ONE 2012, 7, e47132. [CrossRef] [PubMed]

30. Nolles, A. Encapsulation of mTurquoise2 and mTurquoise2-His; Wageningen University \& Research: Wageningen, The Netherlands, 2017.

31. Lindhoud, S.; Norde, W.; Cohen Stuart, M.A. Reversibility and relaxation behavior of polyelectrolyte complex micelle formation. J. Phys. Chem. B 2009, 113, 5431-5439. [CrossRef] [PubMed]

32. Rostkowski, M.; Olsson, M.H.M.; Søndergaard, C.R.; Jensen, J.H. Graphical analysis of pH-dependent properties of proteins predicted using PROPKA. BMC Struct. Biol. 2011, 11, 6. [CrossRef] [PubMed]

33. Olsson, M.H.; Søndergaard, C.R.; Rostkowski, M.; Jensen, J.H. PROPKA3: Consistent treatment of internal and surface residues in empirical pKa predictions. J. Chem. Theory Comput. 2011, 7, 525-537. [CrossRef] [PubMed] 
34. Berman, H.M.; Westbrook, J.; Feng, Z.; Gilliland, G.; Bhat, T.N.; Weissig, H.; Shindyalov, I.N.; Bourne, P.E. The protein data bank. Nucleic Acids Res. 2000, 28, 235-242. [CrossRef] [PubMed]

35. Haupts, U.; Maiti, S.; Schwille, P.; Webb, W.W. Dynamics of fluorescence fluctuations in green fluorescent protein observed by fluorescence correlation spectroscopy. Proc. Natl. Acad. Sci. USA 1998, 95, 13573-13578. [CrossRef] [PubMed]

36. Han, L.; Zhao, Y.; Zhang, X.; Peng, J.; Xu, P.; Huan, S.; Zhang, M. RFP tags for labeling secretory pathway proteins. Biochem. Biophys. Res. Commun. 2014, 447, 508-512. [CrossRef] [PubMed]

37. Nolles, A. CD Spectra of Fluorescent Proteins at $p H 9.0$ or 10.0 and at $p H$ 7.0; Wageningen University \& Research: Wageningen, The Netherlands, 2017.

38. Visser, N.V.; Hink, M.A.; Borst, J.W.; van der Krogt, G.N.M.; Visser, A.J.W.G. Circular dichroism spectroscopy of fluorescent proteins. FEBS Lett. 2002, 521, 31-35. [CrossRef]

39. Brahms, S.; Brahms, J. Determination of protein secondary structure in solution by vacuum ultraviolet circular dichroism. J. Mol. Biol. 1980, 138, 149-178. [CrossRef]

40. Woody, R.W. Circular dichroism. Methods Enzymol. 1995, 246, 34-71. [PubMed]

41. Voets, I.K.; de Keizer, A.; Cohen Stuart, M.A. Complex coacervate core micelles. Adv. Colloid Interface Sci. 2009, 147-148, 300-318. [CrossRef] [PubMed]

42. Blocher, W.C.; Perry, S.L. Complex coacervate-based materials for biomedicine. WIREs Nanomed. Nanobiotechnol. 2016. [CrossRef] [PubMed]

43. Kayitmazer, A.B.; Seyrek, E.; Dubin, P.L.; Staggemeier, B.A. Influence of chain stiffness on the interaction of polyelectrolytes with oppositely charged micelles and proteins. J. Phys. Chem. B 2003, 107, 8158-8165. [CrossRef]

44. Cooper, C.L.; Goulding, A.; Kayitmazer, A.B.; Ulrich, S.; Stoll, S.; Turksen, S.; Yusa, S.; Kumar, A.; Dubin, P.L. Effects of polyelectrolyte chain stiffness, charge mobility, and charge sequences on binding to proteins and micelles. Biomacromolecules 2006, 7, 1025-1035. [CrossRef] [PubMed]

45. Du, X.; Dubin, P.L.; Hoagland, D.A.; Sun, L. Protein-selective coacervation with hyaluronic acid. Biomacromolecules 2014, 15, 726-734. [CrossRef] [PubMed]

46. De Vos, W.M.; Leermakers, F.A.; de Keizer, A.; Cohen Stuart, M.A.; Kleijn, J.M. Field theoretical analysis of driving forces for the uptake of proteins by like-charged polyelectrolyte brushes: Effects of charge regulation and patchiness. Langmuir 2010, 26, 249-259. [CrossRef] [PubMed]

47. Day, R.N.; Davidson, M.W. The fluorescent protein palette: Tools for cellular imaging. Chem. Soc. Rev. 2009, 38, 2887-2921. [CrossRef] [PubMed]

48. Micsonai, A.; Wien, F.; Kernya, L.; Lee, Y.H.; Goto, Y.; Refregiers, M.; Kardos, J. Accurate secondary structure prediction and fold recognition for circular dichroism spectroscopy. Proc. Natl. Acad. Sci. USA 2015, 112, E3095-E3103. [CrossRef] [PubMed]

49. Dolinsky, T.J.; Czodrowski, P.; Li, H.; Nielsen, J.E.; Jensen, J.H.; Klebe, G.; Baker, N.A. PDB2PQR: Expanding and upgrading automated preparation of biomolecular structures for molecular simulations. Nucleic Acids Res. 2007, 35, W522-W525. [CrossRef] [PubMed]

50. Baker, N.A.; Sept, D.; Joseph, S.; Holst, M.J.; McCammon, J.A. Electrostatics of nanosystems: Application to microtubules and the ribosome. Proc. Natl. Acad. Sci. USA 2001, 98, 10037-10041. [CrossRef] [PubMed]

51. Schrödinger, LLC. The MacPyMOL Molecular Graphics System, Version 1.4; Schrödinger, LLC: New York, NY, USA, 2016.

52. Chong, S.; Mersha, F.B.; Comb, D.G.; Scott, M.E.; Landry, D.; Vence, L.M.; Perler, F.B.; Benner, J.; Kucera, R.B.; Hirvonen, C.A.; et al. Single-column purification of free recombinant proteins using a self-cleavable affinity tag derived from a protein splicing element. Gene 1997, 192, 271-281. [CrossRef]

53. Evans, T.C., Jr.; Xu, M.Q. Intein-mediated protein ligation: Harnessing nature's escape artists. Biopolymers 1999, 51, 333-342. [CrossRef]

54. Xu, M.Q.; Paulus, H.; Chong, S. Fusions to self-splicing inteins for protein purification. Methods Enzymol. 2000, 326, 376-418. [PubMed]

55. Biasini, M.; Bienert, S.; Waterhouse, A.; Arnold, K.; Studer, G.; Schmidt, T.; Kiefer, F.; Gallo Cassarino, T.; Bertoni, M.; Bordoli, L.; et al. SWISS-MODEL: Modelling protein tertiary and quaternary structure using evolutionary information. Nucleic Acids Res. 2014, 42, W252-W258. [CrossRef] [PubMed]

56. Arnold, K.; Bordoli, L.; Kopp, J.; Schwede, T. The SWISS-MODEL workspace: A web-based environment for protein structure homology modelling. Bioinformatics 2006, 22, 195-201. [CrossRef] [PubMed] 
57. Kiefer, F.; Arnold, K.; Künzli, M.; Bordoli, L.; Schwede, T. The SWISS-MODEL repository and associated resources. Nucleic Acids Res. 2009, 37, D387-D392. [CrossRef] [PubMed]

58. Guex, N.; Peitsch, M.C.; Schwede, T. Automated comparative protein structure modeling with SWISS-MODEL and Swiss-PdbViewer: A historical perspective. Electrophoresis 2009, 30, S162-S173. [CrossRef] [PubMed]

59. Subach, O.M.; Malashkevich, V.N.; Zencheck, W.D.; Morozova, K.S.; Piatkevich, K.D.; Almo, S.C.; Verkhusha, V.V. Structural characterization of acylimine-containing blue and red chromophores in mTagBFP and TagRFP fluorescent proteins. Chem. Biol. 2010, 17, 333-341. [CrossRef] [PubMed]

60. Wachter, R.M.; King, B.A.; Heim, R.; Kallio, K.; Tsien, R.Y.; Boxer, S.G.; Remington, S.J. Crystal structure and photodynamic behavior of the blue emission variant $\mathrm{Y} 66 \mathrm{H} / \mathrm{Y} 145 \mathrm{~F}$ of green fluorescent protein. Biochemistry 1997, 36, 9759-9765. [CrossRef] [PubMed]

61. Rekas, A.; Alattia, J.R.; Nagai, T.; Miyawaki, A.; Ikura, M. Crystal structure of venus, a yellow fluorescent protein with improved maturation and reduced environmental sensitivity. J. Biol. Chem. 2002, 277, 50573-50578. [CrossRef] [PubMed]

62. Kikuchi, A.; Fukumura, E.; Karasawa, S.; Mizuno, H.; Miyawaki, A.; Shiro, Y. Structural characterization of a thiazoline-containing chromophore in an orange fluorescent protein, monomeric Kusabira Orange. Biochemistry 2008, 47, 11573-11580. [CrossRef] [PubMed]

63. Koppel, D.E. Analysis of macromolecular polydispersity in intensity correlation spectroscopy-Method of cumulants. J. Chem. Phys. 1972, 57, 4814-4820. [CrossRef]

64. Berne, B.J.; Pecora, R. Dynamic Light Scattering with Application to Chemistry, Biology and Physics; Courier Dover: New York, NY, USA, 1976.

65. Provencher, S.W. Contin-A general-purpose constrained regularization program for inverting noisy linear algebraic and integral-equations. Comput. Phys. Commun. 1982, 27, 229-242. [CrossRef]

66. Provencher, S.W. A constrained regularization method for inverting data represented by linear algebraic or integral-equations. Comput. Phys. Commun. 1982, 27, 213-227. [CrossRef]

67. Skakun, V.V.; Hink, M.A.; Digris, A.V.; Engel, R.; Novikov, E.G.; Apanasovich, V.V.; Visser, A.J.W.G. Global analysis of fluorescence fluctuation data. Eur. Biophys. J. 2005, 34, 323-334. [CrossRef] [PubMed]

68. Skakun, V.V.; Engel, R.; Digris, A.V.; Borst, J.W.; Visser, A.J.W.G. Global analysis of autocorrelation functions and photon counting distributions. Front. Biosci. Elite Ed. 2011, 3, 489-505. [CrossRef] [PubMed]

69. Velapoldi, R.A.; Tonnesen, H.H. Corrected emission spectra and quantum yields for a series of fluorescent compounds in the visible spectral region. J. Fluoresc. 2004, 14, 465-472. [CrossRef] [PubMed]

70. Huang, X.Q.; Miller, W. A time-efficient, linear-space local similarity algorithm. Adv. Appl. Math. 1991, 12, 337-357. [CrossRef]

71. Robert, X.; Gouet, P. Deciphering key features in protein structures with the new ENDscript server. Nucleic Acids Res. 2014, 42, W320-W324. [CrossRef] [PubMed]

72. Shealy, P.; Valafar, H. Multiple structure alignment with msTALI. BMC Bioinform. 2012, 13, 105. [CrossRef] [PubMed]

73. Von Stetten, D.; Noirclerc-Savoye, M.; Goedhart, J.; Gadella, T.W., Jr.; Royant, A. Structure of a fluorescent protein from Aequorea victoria bearing the obligate-monomer mutation A206K. Acta Crystallogr. Sect. F Struct. Biol. Cryst. Commun. 2012, 68, 878-882. [CrossRef] [PubMed]

74. Yang, T.T.; Cheng, L.; Kain, S.R. Optimized codon usage and chromophore mutations provide enhanced sensitivity with the green fluorescent protein. Nucleic Acids Res. 1996, 24, 4592-4593. [CrossRef] [PubMed]

(C) 2017 by the authors. Licensee MDPI, Basel, Switzerland. This article is an open access article distributed under the terms and conditions of the Creative Commons Attribution (CC BY) license (http://creativecommons.org/licenses/by/4.0/). 